\title{
BANTUAN BIBIT TANAMAN UNTUK MEMBANTU MENINGKATKAN KUALITAS LINGKUNGAN DI KELURAHAN BAMBU KUNING KECAMATAN TENAYAN RAYA KOTA PEKANBARU
}

\author{
Rini Nizar ${ }^{1}$, Latifa Siswati ${ }^{2}$, Dedi Zargustin ${ }^{3}$ \\ ${ }^{1,2,3}$ Program Studi Agribisnis, Fakultas Pertanian, Universitas Lancang Kuning \\ E-mail: rininizar@unilak.ac.id
}

\begin{abstract}
Urban areas in general shows an increase in population growth and buildings which results in reduced water catchment areas that can cause flooding during the rainy season and also poor air quality that can be generated from forest fires from the surrounding area. This also happened in the Bambu Kuning Village. the team offered to increase youth awareness by providing knowledge about the importance of the environment for human life and with that knowledge young people could implement it into an action or movement. The Lecturer Team cooperates with the Center for Management of Watersheds and Protected Forests in the procurement of seeds. The seeds given are Soursop, Matoa, Mahoni, Pulai, Gaharu and Ketapang Kencana. the implementation of seed assistance not only distributed to Youth Groups RW 09, only Bambu Kuning Village, but there were requests for seeds from other parties. Other parties are: residents in RW 013 East Sidomulyo Village Marpoyan Damai Subdistrict, Agricultural Vocational High School, 6th High School, Zamrad Kindergarten, 8th Vocational School, Nature Unilak Student Student Group and Unilak BEM Student Organization. An interesting finding in the field is the desire of the Senior High School Negeri 8 in Palas to make cooperation for lecturers to do PKM in their schools for students in the school who need to be followed up.
\end{abstract}

Keywords: Greening, Seed Aid, Planting

\begin{abstract}
Abstrak
Di daerah perkotaan pada umumnya menunjukkan adanya peningkatan pertumbuhan penduduk dan bangunan yang mengakibatkan berkurangnya daerah resapan air yang dapat menimbulkan banjir pada musim hujan dan juga kualitas udara yang kurang baik yang bisa ditimbulkan dari kebakaran hutan dari daerah disekitarnya. Hal ini juga terjadi di Kelurahan Bambu Kuning, untuk itu tim menawarkan untuk meningkatkan kepedulian pemuda dengan memberikan pengetahuan tentang pentingnya lingkungan hidup bagi kehidupan manusia dan dengan pengetahuan tersebut pemuda dapat mengimplementasikannya kedalam suatu tindakan atau gerakan. Tim Pengabdian Dosen bekerjasama dengan Balai Pengelolaan Daerah Aliran Sungai dan Hutan Lindung dalam pengadaan bibit. Bibit yang diberikan adalah bibit Sirsak, Matoa, Mahoni, Pulai, Gaharu dan Ketapang Kencana. Dalam pelaksanaan bantuan bibit tidak saja didistribusikan ke Kelompok Pemuda RW 09 Kelurahan Bambu Kuning saja, tetapi ada permintaan bibit dari pihak lainnya. Pihak lain tersebut adalah: warga di RW 013 Kelurahan Sidomulyo Timur Kecamatan Marpoyan Damai, SMK Pertanian, SMA N 6, TK Zamrad, SMK N 8, Kelompok Mahasiswa Pencinta Alam Unilak dan Organisasi Mahasiswa BEM Unilak. Temuan yang menarik di lapangan adalah adanya keinginan dari SMA $N 8$ Kelurahan Palas untuk membuat kerjasama bagi dosen untuk melakukan pengabdian di sekolahnya untuk siswa-siswa di sekolah tersebut yang perlu untuk ditindak lanjuti.
\end{abstract}

Kata kunci : Penghijauan, Bantuan Bibit, Penanaman 


\section{PENDAHULUAN}

Pesatnya perkembangan Kota Pekanbaru berpotensi menggeser keberadaan Ruang Terbuka Hijau (RTH) di Kota Pekanbaru. Dalam evaluasi Rencana Umum Tata Ruang (RUTR) Kota Pekanbaru tahun 1991, arahan kawasan non terbangun khususnya yang berfungsi sebagai kawasan lindung pada tahun 2015 diidentitifikasikan dalam RUTR Kota Pekanbaru seluas 16.768 Ha. Kenyataannya pada tahun 2006 kawasan lindung baru mencapai 2.487,65 Ha. Dalam perjalanan pengembangan kawasan lindung Kota Pekanbaru hingga tahun 2015 telah terjadi alih fungsi lahan peruntukan kawasan lindung menjadi kawasan terbangun seperti pemukiman, perdagangan, industri, perkebunan, dan semak belukar. Bergesernya keberadaan RTH di Kota Pekanbaru dapat menjadikan Kota Pekanbaru menjadi tidak nyaman, salah satunya ditunjukkan oleh tingginya suhu di Kota Pekanbaru mencapai 34o C-35o C (Media Indonesia, 2010) dalam (Lis Noer Aini dkk, 2015), selain itu juga berkurangnya daerah resapan air yang mengakibatkan banjir pada musim hujan.

Salah satu Kelurahan yang lahan pinggiran jalan dan halaman rumah penduduk yang masih ditanami dengan tanaman peneduh adalah RW 09 Kelurahan Bambu Kuning Kecamatan Tenayan Raya Kota Pekanbaru.

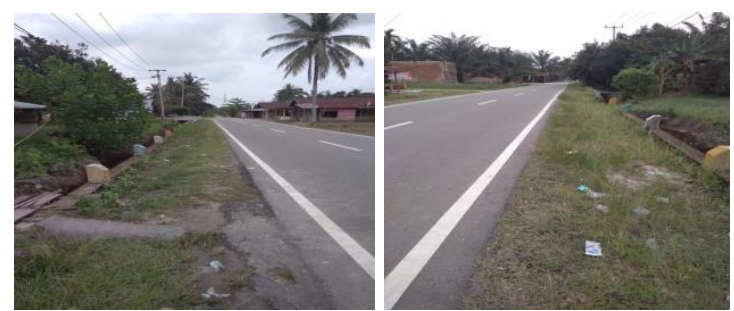

Gambar 1. Jalan di RW 09 Kel. Bambu Kuning

Panasnya suhu di Kota Pekanbaru akan cocok bila diberikan atau ditanam pohon pada pinggiran jalan. Manfaat pohon yang ditanam di pinggir jalan ini adalah menghasilkan oksigen yang dibutuhkan oleh manusia, membuat sejuk karena dapat menyerap panas, menjaga kelembaban, dapat menyerap debu, membuat indah jalan dan dapat menjadi tempat berteduh bagi pejalan kaki.

Kegiatan penanaman pohon dipinggir jalan dapat merupakan kegiatan penghijauan. Menurut Kevin, 2008 dan Malau (2012) dalam Eko Anton Rubiantoro dan Ragil Haryanto (2013) dalam konteks keruangan, penghijauan sangat dibutuhkan terutama untuk kota-kota yang sedang berkembang dan mengalami alih fungsi ruang untuk kawasan terbangun, penghijauan sangat dibutuhkan untuk menciptakan lingkungan yang sejuk, segar, nyaman dan sehat.

\section{METODE}

Responden adalah kelompok pemuda RW 09 Kelurahan Bambu Kuning, Sekolah- Sekolah dan warga RT 013 Kelurahan Sidomulyo Timur. Kegiatan Pengabdian ini dilaksanakan dengan tahapan sebagai berikut:

\subsection{Pengajuan bantuan bibit}

Permohonan bantuan bibit kepada responden di ajukan ke Balai Pengelolaan Daerah Aliran Sungai dan Hutan Lindung Indragiri Rokan Kementerian Lingkungan Hidup Dan Kehutanan.

\subsection{Distribusi Bibit}

Distribusi bibit dibagikan yang utama adalah kepada Kelompok Pemuda RW 09 Kelurahan

Bambu Kuning Kecamatan Tenayan Raya. Namun dalam pelaksanaannya banyak pihak lain yaitu Sekolah-sekolah, warga di RW 13 juga meminta bibit dan ketersediaan memungkinkan untuk diberikan, maka penerima bantuan bibit lebih dari satu kelompok masyarakat. Penyerahan bibit disertakan dengan berita acara penyerahan bibit 


\subsection{Penanaman Bibit}

Kegiatan penanaman bibit dilakukan hanya di RW 09 Kelurahan Bambu Kuning yang dilakukan oleh Kelompok Pemuda dan Tim Dosen.
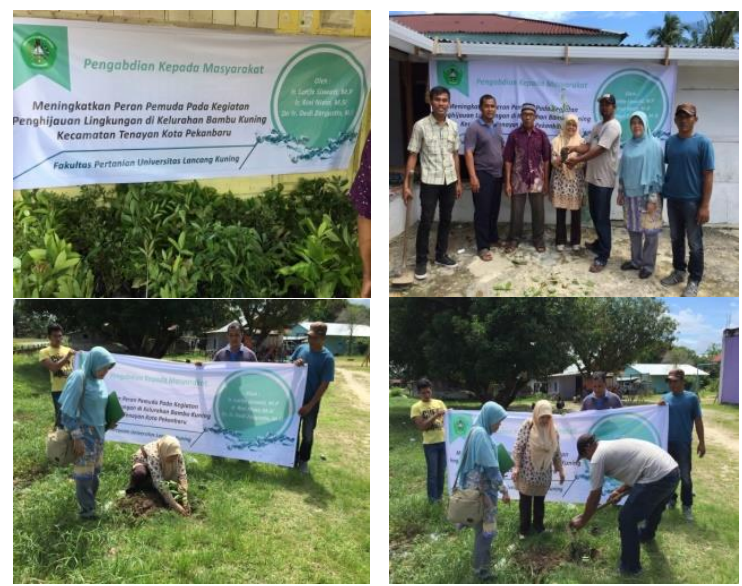

Gambar 2. Kegiatan Penanam oleh Kelompok Pemuda dan Tim Dosen

\subsection{Pendampingan dan evaluasi hasil.}

Kegiatan pendampingan dan evaluasi dilakukan untuk memantau penanaman bibit yang dilakukan oleh kelompok pemuda.

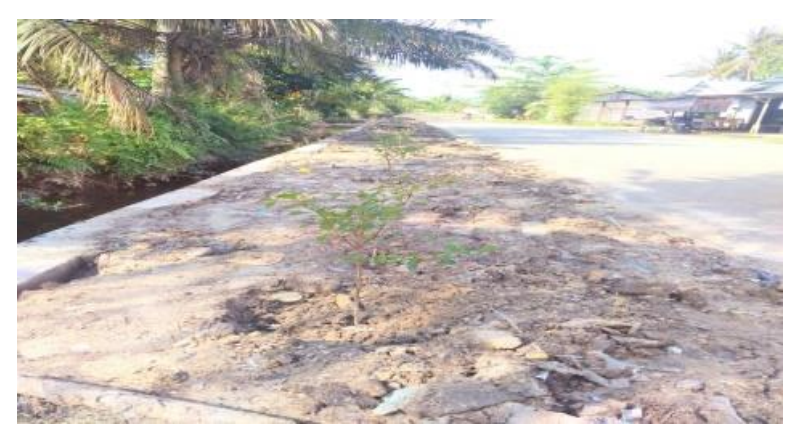

Gambar 3. Bibit yang telah ditanam dipinggir jalan oleh Kelompok Pemuda RW 09

\section{HASIL DAN PEMBAHASAN}

Kelompok Pemuda RW 09 Kelurahan Bambu Kuning Kecamatan Tenayan Raya sangat aktif untuk bekerjasama dengan Tim Dosen Faperta Unilak. pengurus kelompok pemuda 09 Kelurahan Bambu Kuning Kecamatan Tenayan Raya menyatakan bahwa bantuan bibit ini memang diperlukan terutama untuk peneduh dan meningkatkan kualitas udara yang nantinya dapat menciptakan lingkungan yang sejuk, segar, nyaman dan sehat.

Bibit tidak saja diberikan kepada Kelompok Pemuda RW 09 Kelurahan Bambu Kuning Kecamatan Tenayan Raya tetapi juga diberikan Ke sekolah-sekolah di Kota Pekanbaru, Warga dan juga Kelompok Mahasiswa Unilak. Berikut ini adalah foto-foto distribusi bibit yang diberikan oleh Tim Dosen. 

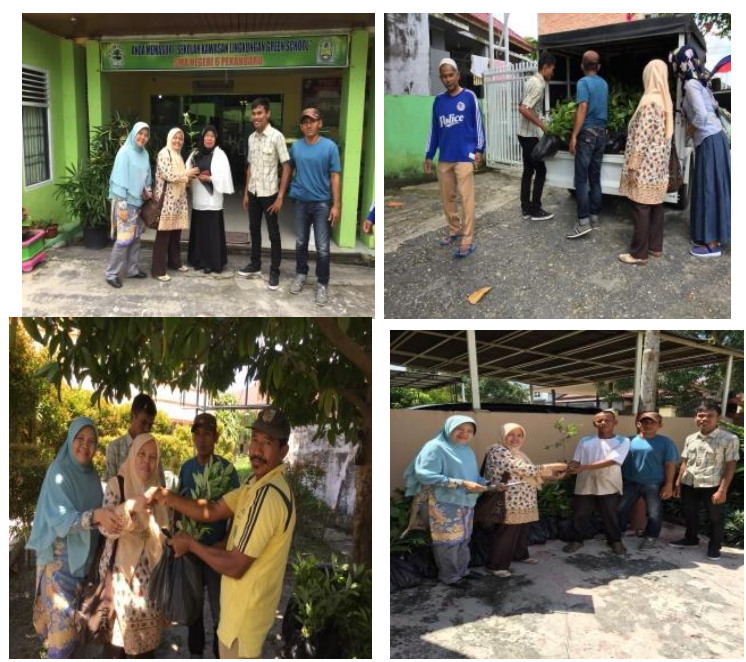

Gambar 4. Distribusi bibit ke warga masyarakat dan sekolah

Dari kegiatan pengabdian ini ada hal yang menarik untuk ditindaklanjuti yaitu permintaan dari SMK N 8 Kelurahan Palas Kecamatan Rumbai yang menginginkan adanya kerjasama yang berkelanjutan dengan Tim Dosen untuk melakukan pengabdian di SMK N 8 terutama dalam hal proses pembuatan pupuk organik dan kegiatan kewirausahaan seperti budidaya jamur tiram dan pengolahannya. Sementara warga masyarakat dan sekolah banyak juga yang meminta bantuan bibit tanaman buah-buahan.

\section{KESIMPULAN}

Warga Masyarakat maupun sekolah dan kelompok mahasiswa menerima bantuan bibit yang diberikan oleh Tim Dosen dengan baik dan dimanfaatkan untuk kegiatan penanaman. Yang nantinya diharapkan dapat memberikan lingkungan yang sejuk, segar, dan sehat bagi lingkungan disekitarnya

\section{SARAN}

Perlu ditindaklanjuti tawaran dari SMK N 8 Kelurahan Palas Kecamatan Rumbai untuk menjalin kerjasama di kegiatan pengabdian masyarakat dan bantuan bibit tanaman buah-buahan

\section{UCAPAN TERIMA KASIH}

Penulis mengucapkan terima kasih kepada Balai Pengelolaan Daerah Aliran Sungai dan Hutan Lindung yang telah memberi dukungan bibit tanaman dan Fakultas Pertanian yang telah memberi dukungan financial terhadap kegiatan ini.

\section{DAFTAR PUSTAKA}

[1] Lis Noer Aini, Bambang Heri Isnawan, Endri Ridwan Saleh. 2015. Evaluasi Ruang Terbuka Hijau di Kota Pekanbaru. Planta Tropika Journal of Agro Science Vol 3 No $1 /$ Februari 2015. DOI 10.18196/pt.2015.038.41-51

[2] Ahmad Rafli Anhar. 2015. Pemuda sebagai Agen Perubahan. www. Kompasiana.com. upload 26 Juni 2015. Diakses 3 November 2018.

[3] Eko Anton Rubiantoro, Ragil Haryanto. 2013. Bentuk Keterlibatan Masyarakat dalam Upaya Penghijauan pada Kawasan Hunian Padat di Kelurahan Serengan - Kota Surakarta. 
Jurnal Pembangunan Wilayah dan Kota. Biro Penerbit Planologi Undip Volume 9 (4): 416-428 Desember 2013.

[4] Tenny Intani K, Elis Tambaru, Muhtadin Asnady Salam, 2013. Keanekaragaman Morfologi Daun Pohon Penghijauan Di Jalan Perintis Kemerdekaan Kota Makasar. Jurusan Biologi, Fakultas Matematika dan Ilmu Pengetahuan Alam. Universitas Hasanudin. Makasar. Jurnal Alam dan Lingkungan, Vol.4 (7) Agustus 2013. 